\title{
The professional skills profile of a public affairs practitioner in Spain
}

\author{
María Paola Mastrantonio iD, Oscar Coduras iD \\ Euncet Business School (Universitat Politècnica de Catalunya) (Spain) \\ mpmastrantonio@euncet.es,oscar.coduras@euncet.es
}

Received August, 2017

Accepted March, 2018

\begin{abstract}
Purpose: The present study identifies the professional skills profile that a Public Affairs (PA) practitioner of a major company or an organization representing the interests of various economic sectors should have in Spain.

Design/methodology: The study uses a mixed qualitative and quantitative methodology. The initial identification of the competences, as well as the general functions of the profile to be evaluated, has been carried out using the in-depth interview technique with the directors of APRI (Association of Professionals of Institutional Relations of Spain), who defined these competencies from their expert perspective. Subsequently, through a survey of seventy-two managers, sufficient data were obtained to statistically process the information and obtain significant results in the identification of such competences. This information has been processed, firstly, through factorial analysis, which has made it possible to synthesize these competences. Once the analysis of factors was carried out, a cluster analysis is added for the classification of the respondents or managers.
\end{abstract}

Findings: The perception of the interviewed executives has been determined regarding the functions that an institutional relations practitioner must fulfill. It should be noted that this is a profession for which there is no clarity about the role and the legitimacy of its members, particularly in Spain. In fact, it is associated with a function that is seen as exerting undue pressure on political power. A field study was conducted to determine the opinion of these managers on the competences that a professional in institutional relations should have.

Originality/value: This study provides a description of the job position of a person responsible for institutional relations in Spain. Moreover, it adds a typology of managers, according to the competences defined for the person responsible for institutional relations.

Keywords: Institutional relations, Lobby, Interest group, Job description

Jel Codes: M5

\section{To cite this article:}

Mastrantonio, M.P., \& Coduras, O. (2018). The professional skills profile of a public affairs practitioner in Spain. Intangible Capital, 14(4), 569-583. https://doi.org/10.3926/ic.1136 


\section{Introduction}

The key question of the research conducted was: What are the competences that a professional responsible for institutional relations must have? The sponsor of this research has been the Association of Professionals of Institutional Relations (APRI), a national association of a non-profit, non-political nature, which was formed in December 2007 with the aim of filling a gap that exists in Spain in the representation and association of professionals in institutional relations. It brings together and represents all natural persons who voluntarily wish to form part of the same and whose main professional activity is centered on institutional relations, or lobbying, understood as the functions of transmitting and defending legitimate sectoral interests with the public administrations in general, and in particular, with the legislative and executive powers at a European, state and autonomic level (APRI, 2016). This association is aware of the scarce institutional development that these legitimate practices have in Spain, and furthermore, the bad reputation that accompanies them. Accordingly, the professionals belonging to the association attempt to engage in actions aimed at greater transparency in the system. This has already led to the signing of a code of conduct which must be followed by all members and the creation of a voluntary public register of lobbyists within the partners, as is already the case in Brussels.

One of the difficulties that those responsible for institutional relations typically find in their management is defining the requirements, in terms of competences, for the position they hold in order to have a reliable reference with which to cover possible vacancies in their organizations; i.e., the job description (Mondy, 1997; Chiavenato, 1999). The work presented in this article provides an answer to this problem and contributes to the development of the discipline (public affairs).

\section{Review of the literature}

\subsection{Institutional relations}

The Public Affairs Council (PAC) defines institutional relations ("public affairs") as "the managerial function responsible for the interpretation of the corporation's non-commercial environment and the direction and management of the company's response to these factors." In all advanced nations, institutional relations or lobbying have been considered for decades to be an essential instrument for the public defense of private interests (both collective and individual), a fundamental tool for transparency and an effective barrier against corruption. Therefore, a vast body of literature can be found in relation to institutional relations, primarily in countries where these professionals play an important role in the decision-making of modern democratic societies (Von den Driesch \& Van der Wurff, 2016). The large number of articles from academic journals demonstrates the interest in analyzing and investigating institutional relations. As early as 1963, Milbrath provided a widely accepted definition, establishing that institutional relations are a communicative act that aims to influence government officials. The definition by the PAC (2016) initially mentioned comes from that provided by Windsor (2005), in which he proposes that institutional relations are the interface between corporations and their non-commercial environments. This definition serves as a basis, in turn, for that by McGrath, Moss and Harris (2010), who situate institutional relations as a nexus between the politics, management and communication.

However, despite the progress made in terms of the volume of publications on the topic, a recent study (Davidson, 2015) concludes that there is not yet a mature body of knowledge on institutional relations. Not only that, there is also no consensus on the concept of institutional relations, as some authors consider them to form part of public relations, while others see them as an independent field of study (de Lange, 2000).

The defenders of the institutional relations as a corpus of independent knowledge establish that they determine to a greater extent the success or failure of an organization than any other area of public relations (Tusinki, 2009). Moreover, some authors position the category of institutional relations above that of public relations, considering the former to be a strategic role with higher status (L'Etang, 2008), whose leaders influence the configuration of the internal and external realities of the organization (de Lange \& Linders, 2006), participating in dialogs at a governmental level that are much more complex than those of public relations (Beurer, Zeullig, Fieseler \& Meckel, 2009; Harris \& Moss, 2001). 
On the other hand, institutional relations cannot be conceptualized without mentioning the article by McGrath et al. (2010) which, based on a synthesis of the views of some of the leading scholars and exponents on institutional relations, defines them as the activities covering all corporate functions related to the management of an organization's reputation, external audiences, lobbying or governmental relations, media relations, governance and relationships with the community (Post, 1982; Toth,1986; Dennis, 1996; Fleisher, 2001; Harris \& Fleisher, 2005; Lerbinger, 2006; Allen, 2012; Berg, 2009).

One confusion that exists, at least in Spain, is the difference between a pressure group and an interest group or lobby, which gives the negative connotation to institutional relations (Jerez, 2000). When an interest group uses its action to pressure the center of political decision-making, even using coercive means, it is called a pressure group (Álvarez \& Montalvo, 2014). The role of institutional relations or lobbying is to carry out actions to influence the public powers in defense of the common interests of its members (Rubio Núñez, 2003), always through the prism of transparency.

"While in all advanced nations, lobbies are considered to be an essential tool for transparency and an effective barrier against corruption, in our country they are still an incomprehensible pending subject" (Transparency International España, 2014).

This ultimately corroborates the state of underdevelopment that characterizes institutional relations in Spain, as compared to other developed countries. In a political context such as the present, the regulation of lobbies in Spain is still being discussed without even overcoming the conception of lobby as a synonym for corruption.

In Spain, there is still a debate about the desirability of expressly regulating institutional relations. On the one hand, it has addressed the desirability of regulating the role of interest groups on a national level, but also how said regulation needs to underscore a better defense of the interests in the area of decision-making in the European Union (Morata, 1995; Xifra, 2011).

In Spain, in the absence of any regulation, the professionals in institutional relations (APRI) themselves have defined them as the function of transmitting legitimate interests to the public administrations in general, and in particular, to the legislative and executive powers at the European, state and regional levels (APRI, 2016). In addition, a code of conduct and a member registry have also been created.

All of this suggests that institutional relations are an organizational activity that practitioners and academics will continue to define and redefine, the limits of which are today unclear; it is a function that is still searching for its own clear identity. The lack of regulation in Spain only generates a weakness as compared to the interest groups that are in Brussels, exercising their functions, in a legitimate and validated manner. The good news is that, with the aim of enhancing transparency and good governance, the Parliament of Catalonia has approved the first regulation of lobbies in Spain, through Title IV of Act 19/2014 (Bartlett \& Vèrnia, 2015). From an optimistic perspective, practitioners are constantly expanding their role, and scholars will face an ongoing challenge to keep up with the real-world developments in the field and the development of the profession mentioned above.

\subsection{The functions of institutional relations practitioners}

This permanent revision and redefinition of institutional relations brings with it a lack of limits in the conception of the functions exercised by those responsible for them.

In the development of the literature on these functions, special emphasis is placed on the fact that they have changed over the years and this is undoubtedly influenced by the context in which they are developed. For example, Marcus and Irion (1987) suggest that the Corporate Public Affairs departments typically have four key functions: government relations, public relations, educational support, philanthropy and the like. Lord (2000) and Hawkinson (2005) include crisis management, problem management and employee relations. In 2009, the Center for Corporate Governance in Asia conducted a study to define the functions of institutional relations practitioners, identifying the most relevant as being corporate communications, corporate social responsibility, crisis management, community relations, relations with stakeholders, government relations, the monitoring of 
trade associations, problem management, media relations, communications with employees and philanthropy. It is clear that such a broad list demonstrates that, in this Asian study, there is no differentiation between public relations and institutional relations.

In a recent study conducted by Von den Driesch and Van der Wurff (2016) on the roles (understood as functions) played by those responsible for institutional relations in Holland, these researchers describe how professionals understand their work and social function and how they believe they must do their work, from the perspective of a shared, rather than an individual reflection by the members of the profession. The authors identify three roles or functions of those responsible for institutional relations. In the first case, their main function is to defend the interests of their client or fight in the political arena for their client; this is the so-called ombudsman function. This is also the most commonly recognized function in Spain, since the leaders of the APRI mention it as relevant. In the second case, the practitioners consider that their main function is to provide knowledge and information so that decision-makers (politicians) can make informed decisions; they are the socalled experts. And the third type are the practitioners who focus their functions on representing the interests of their organization, but also the interests of society in general. These are the mediators who always strive for consensus. The conclusions of the study establish that those responsible for institutional relations in Holland see themselves, first of all, in the functions of advocates; secondly, as experts; and finally, as mediators. These three roles are seen as specialties within the profession, giving one of them priority over the rest.

In the case of Spain, there are more and more large corporations that have professionals specialized in institutional relations, something that is not unique to them, since these practitioners are also employed by business organizations and trade unions, industry associations and professional groups, consulting firms specialized in this practice, non-governmental organizations and, of course, governmental institutions at the different levels of administration. However, according to the APRI, there is little institutional development of these practices and, moreover, they are accompanied by the bad reputation perceived by society in general. Proof of the boom of lobbyingand the need for professionalization is the proliferation of courses that are being launched by some universities and business schools, in spite of the fact that it is unclear what the role of these professionals is.

As mentioned above, one of the obvious difficulties for the management of the institutional relations in corporations or other organizations is the ability to recruit professionals with the right competences (capacity building) for the performance of the profile functions (Levy-Leboyer, 2003), since if these are not clearly defined, it is difficult to define, in turn, the requirements in terms of skills of those who must perform them.

\section{Methodology}

The research, carried out in three phases, utilized both quantitative and qualitative techniques, since its approach consisted of initially identifying the profile competences from the expert knowledge perspective. These were then endorsed by the most important active professionals in the Spanish corporate sector.

Thus, in the first phase, in-depth interviews were conducted with the six directors of the Association of Professionals of Institutional Relations (APRI), whose opinion was considered to represent expert opinion, by virtue of the activity they perform and the framework in which it is performed.

These interviews enabled us to identify a priori the professional competences that the experts consulted considered to be ideal for the profile analyzed. In order to endorse them and calibrate their importance, these were then used in the construction of a questionnaire (López-Roldán \& Fachelli, 2016). This questionnaire addressed business professionals and business associations in the sector, and was complemented with requests to evaluate various aspects inherent to the experience expected for the performance of the function (Louart, 1994), as well as initial or basic training. 


\subsection{The sample}

As designed, the questionnaire targeted a limited sample of professionals exercising the subject matter being studied, having used a non-random sampling method with discretionary selection of representative sampling units, at the researcher's discretion.

The method of this type of sampling is oriented toward obtaining representative samples through the inclusion of supposedly typical individuals in the subject matter being investigated, and therefore, with a thorough understanding of and experts in the field.

Given that the task was to gather opinion and assess a specific topic (the professional skills that a professional in institutional relations must possess) that is not generalizable to the population as a whole, and striving for objectivity, a first profile of interviewees was defined for a base study sample, followed by a second profile to contrast with the previous one, in order to verify the concordance or divergence of opinions and ratings between the two groups on the subject being considered.

For the base sample denominating the study, the profile of managers linked to the administration and/or management of institutional relations in companies with the highest turnover operating in Spain was defined, having selected a sample of 50 managers from among the 160 companies with the highest turnover, i.e. those invoicing more than $€ 875$ million and which, given their size in terms of turnover, had professionals with this profile on staff. With respect to the activity sectors, the managers surveyed worked in companies in the automotive, banking, trade, construction, consulting, appliance, electronics, renewable energy, food and beverage, metallurgical, manufacturing, engineering, chemical, pharmaceutical laboratory, airline, oil \& gas, insurance, telecommunications, tourism and travel and new information and communication technologies industries. As can be seen, there is no dependence on the economic sector in question, but rather on the size of the company.

In addition, as a contrast sample to the base sample, we selected directors from sector business associations in the main sectors of economic activity in Spain, having initially selected a sample of 20 managers and with 22 individuals ultimately being included in the study.

\subsection{Data collection}

For field work, an online platform was created to collect the responses to the questionnaire the respondents accessed by means of a link sent to them by e-mail.

The platform housed the databases of the sampling units and the questionnaires filled out by respondents. The responses were initially compiled in an Excel file, the data from which were transferred to SPSS and then processed statistically.

The system used to collect the responses excluded the "does not know/does not respond" and "non-response" (missing) options, as the sampling units were sufficiently knowledgeable about the topic, so the computing mechanism forced the respondents to answer each question in order to move on in the questionnaire. It is for this reason that the report does not consider these response parameters.

\section{Analysis of the results}

\subsection{Results of the in-depth interviews}

The following results were obtained from the in-depth interviews:

\subsubsection{Experience required for the position}

According to the interviewees, there are four requirements that may be considered necessary to assume a position of responsibility in the institutional relations of a Spanish company: having previously worked in the same sector of activity, that is to say, the candidates have knowledge of the productive sector; having worked in the field of institutional relations in other organizations, i.e., the candidates have previous experience in similar 
positions; coming from the world of politics and thus have an understanding of governance and parliamentary procedures, and preferably having international experience with special emphasis on the countries of the European Union.

\subsubsection{Initial training required for the position}

Experts who knew this position well were consulted about the initial training that those responsible for institutional relations must have. Among those mentioned were the professions of Public Relations, Business Administration and Management, Political Science, Communications and Sociology. The responses with the highest frequency and smallest standard deviation were the careers of Public Relations and Business Administration and Management.

\subsubsection{Competences required for the job}

In the in-depth interviews, fifteen professional competences were identified which, as previously mentioned, were used in the questionnaires. The respondents were asked to rate the need for these competences in order to perform the tasks related to institutional relations.

Below is a list of each of the competences: 10 knowledge-based competences and 5 skill-based competences.

\begin{tabular}{|c|l|}
\hline Number & \\
\hline 1 & Knowledge about the decision-making process \\
\hline 2 & Knowledge of current legislation \\
\hline 3 & Socio-economic knowledge \\
\hline 4 & Knowledge of economic-financial management \\
\hline 5 & Socio-political knowledge \\
\hline 6 & Knowledge of corporate communications \\
\hline 7 & Marketing knowledge \\
\hline 8 & Knowledge of international relations \\
\hline 9 & Knowledge of organizational strategy \\
\hline 10 & Languages \\
\hline 11 & Written communication \\
\hline 12 & Oral communication \\
\hline 13 & Diplomatic and relationship skills \\
\hline 14 & Negotiating capacity and strategic vision \\
\hline 15 & Skills for the management and direction of work areas and teams \\
\hline
\end{tabular}

Table 1. Competences defined by the experts

\subsection{Results of the quantitative analysis}

\subsubsection{Experience required for the position}

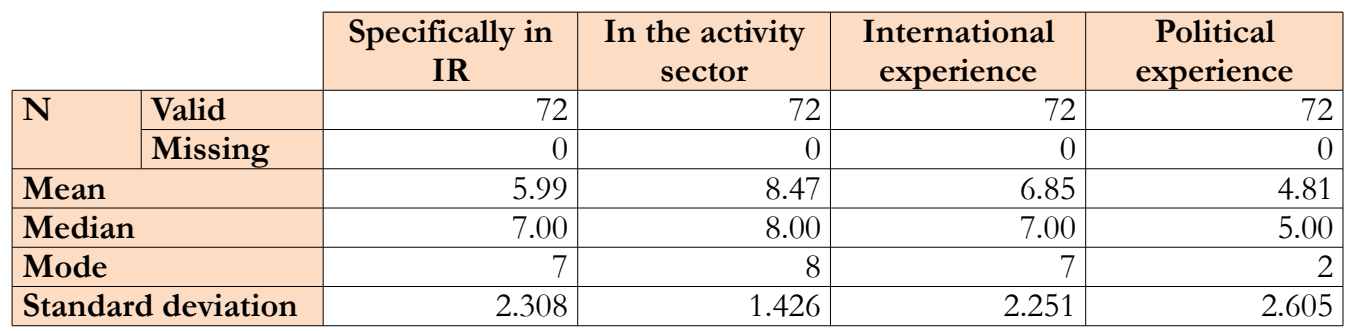

Table 2. Experience required for the position

According to the information given in the table above, the respondents believe that the most relevant experience required for the position is knowledge of the activity sector, followed by international experience and specific experience in institutional relations. Apparently, they believe that political experience is not relevant in terms of 
assuming a position of responsibility in institutional relations. Faced with the question "What type of entity do you turn to in order to select a candidate to form part of the department in charge of public affairs in your organization?", the answers are consistent with these results, since the largest number of those polled answered referring to companies in the same sector and industry associations as sources of professional recruitment.

\subsubsection{Competence analysis through factor analysis}

Once the results had been obtained, the question asked by the researchers was whether it was possible to reduce the dimensionality of the data set to facilitate their interpretation, while losing the least amount of information possible. To answer this question, we used the factor analysis and, in particular, principal components analysis.

Once the information from the ratings compiled in the field work was synthesized, the necessary conditions were checked in order to decide whether the principal components analysis method could be used. The sample size corresponds to a number greater than 50 subjects ( 72 respondents). In the case of Bartlett's test of sphericity, the result had a level of significance of less than 0.05 , which indicates that the use of the method is appropriate. In the case of the KMO (Kayser, Meyer and Olkin) index, the results showed a level close to 0.8. According to Kayser, low values for the KMO index make it ill advised to use factor analysis, but in this case, we obtained a level of 0.8 , which implies a good level. All in all, it can be said that it is plausible to use the principal components method (PCM).

\begin{tabular}{|c|c|c|c|c|c|c|c|}
\hline \multirow[b]{2}{*}{ Component } & \multicolumn{3}{|c|}{ Initial eigenvalues } & \multicolumn{3}{|c|}{$\begin{array}{c}\text { Sums of squared saturations of } \\
\text { the extraction }\end{array}$} & \multirow{2}{*}{$\begin{array}{l}\text { Sums of squared } \\
\text { saturations of the } \\
\text { rotation }\end{array}$} \\
\hline & Total & $\%$ variance & $\%$ cumulative & Total & $\%$ variance & $\%$ cumulative & \\
\hline 1 & 6.100 & 40.669 & 40.669 & 6.100 & 40.669 & 40.669 & 24.841 \\
\hline 2 & 2.034 & 13.560 & 54.229 & 2.034 & 13.560 & 54.229 & 21.326 \\
\hline 3 & 1.839 & 12.258 & 66.487 & 1.839 & 12.258 & 66.487 & 14.722 \\
\hline 4 & 1.038 & 6.920 & 73.408 & 1.038 & 6.920 & 73.408 & 12.518 \\
\hline
\end{tabular}

Extraction method: principal component analysis

Table 3. Factor analysis. Principal Component Analysis

Once the data were processed, as shown in the table above, the information provided by the SPSS program indicates that there were four main components that explain a little more than $73.4 \%$ of the total variance.

The rotated component matrix defined the four factors and their composition in terms of variables: 


\begin{tabular}{|l|r|r|r|r|c|}
\cline { 2 - 5 } \multicolumn{1}{c|}{} & \multicolumn{3}{c|}{ Component } & Commonalities \\
\cline { 2 - 6 } \multicolumn{1}{c|}{} & \multicolumn{1}{c|}{$\mathbf{1}$} & $\mathbf{2}$ & $\mathbf{3}$ & \multicolumn{1}{c|}{4} & \\
\hline Socio-economic knowledge & $\mathbf{0 . 8 1 8}$ & 0.343 & 0.062 & 0.006 & 0.805 \\
\hline Knowledge of economic-financial management & $\mathbf{0 . 7 7 7}$ & 0.317 & -0.171 & 0.058 & 0.746 \\
\hline Knowledge of organizational strategy & $\mathbf{0 . 7 1 9}$ & 0.040 & 0.150 & 0.453 & 0.757 \\
\hline Knowledge of marketing & $\mathbf{0 . 6 5 0}$ & -0.191 & 0.331 & 0.333 & 0.691 \\
\hline Socio-political knowledge & $\mathbf{0 . 5 8 1}$ & 0.542 & 0.230 & -0.045 & 0.697 \\
\hline Oral communication & -0.016 & $\mathbf{0 . 8 2 1}$ & 0.125 & 0.237 & 0.759 \\
\hline Knowledge about the decision-making process & 0.210 & $\mathbf{0 . 7 8 0}$ & 0.130 & -0.216 & 0.725 \\
\hline Written communication & 0.052 & $\mathbf{0 . 7 7 6}$ & 0.027 & 0.319 & 0.726 \\
\hline Knowledge of current legislation & 0.474 & $\mathbf{0 . 6 2 5}$ & -0.006 & -0.039 & 0.631 \\
\hline Negotiating capacity and strategic vision & 0.276 & $\mathbf{0 . 5 2 6}$ & 0.442 & 0.262 & 0.612 \\
\hline Skills for the management and direction of teams & 0.078 & 0.056 & $\mathbf{0 . 8 7 1}$ & 0.131 & 0.801 \\
\hline Diplomatic and relationship skills & -0.494 & 0.227 & $\mathbf{0 . 7 0 5}$ & -0.028 & 0.804 \\
\hline Knowledge of corporate communications & 0.474 & 0.129 & $\mathbf{0 . 6 9 0}$ & 0.151 & 0.743 \\
\hline Knowledge of international relations & 0.076 & 0.090 & 0.134 & $\mathbf{0 . 8 6 0}$ & 0.757 \\
\hline Languages & 0.510 & 0.358 & 0.119 & $\mathbf{0 . 5 8 8}$ & 0.752 \\
\hline
\end{tabular}

Extraction method: principal component analysis

Rotation method: Varimax with Kaiser normalization

a. The rotation has converged in 23 iterations.

Table 4. Factor analysis. Rotated component matrix

The commonalities express which of the individual variables are the most important in explaining the problem, which is the definition of a competence profile. As a general rule, they must be greater than 0.4; in the case investigated, all are above 0.612 , so no variable should be ruled out.

The solution allows the competences to be grouped into four relevant factors of the professional profile of the person responsible for institutional relations:

The first factor, with 5 components greater than 0.581 , explains $40.669 \%$ of the variance. It was called cognitive factor, as it includes the competences of socio-economic knowledge, knowledge of economic-financial management, knowledge of organizational strategy, knowledge of marketing and socio-political knowledge.

The cognitive component relates mainly to the knowledge base, to the know-how the person responsible for institutional relations must have and that defines the initial training required for the job, the qualification (or degree) that he/she must have completed.

The second factor, with 5 components greater than 0.526 , explains $13.56 \%$ of the variance and was termed the procedural factor. It includes the following competences: oral communication, knowledge about the decisionmaking process, written communication, knowledge about current legislation, and the capacity for negotiation and strategic vision.

This component refers to know-how, to the procedures to be carried out by the candidates during the performance of their functions and which are the set of actions that facilitate the achievement of the goals proposed for the position.

The third factor, with 3 components greater than 0.690 , explains $12.258 \%$ of the variance and can be defined as the relational factor. It includes the skills for the management and direction of work areas and teams, diplomatic and relationship skills and knowledge of corporate communications.

Relationship skills are linked to know-how, communication skills, coexistence, ensuring mediation when conflicts arise and promoting collaboration, among other skills; they allow for a healthy relationship with other people and institutions. 
Finally, the fourth factor includes 2 components greater than 0.588 , which explains the $6.92 \%$ of the variance; it is referred to as the international factor. It includes knowledge of international relations and languages.

This fourth factor, the international factor, makes reference to the need associated with the job position for the candidate to possess certain skills, such as languages for engaging in international relations conducive to the development of the organization in global environments, particularly at the European level.

\subsubsection{Hierarchical cluster analysis}

Next, a hierarchical cluster analysis of the individuals surveyed was performed to group them according to similar characteristics of their responses. Cluster analysis refers to the technique used to determine the underlying structure or natural grouping of a set of entities (managers), illustrating which of these entities are most closely related on the basis of a set of descriptors (skills). We applied cluster analysis in the area of the factors or components obtained from the principal component analysis to the data from the study on the professional competences of those responsible for institutional relations.

The following table shows the mean and standard deviation for each competence:

\begin{tabular}{|l|r|r|}
\hline \multicolumn{1}{|c|}{ Competence } & Mean & \multicolumn{1}{c|}{ Standard deviation } \\
\hline Knowledge about the decision-making process & 9.27 & 0.865 \\
\hline Knowledge of current legislation & 8.28 & 1.7525 \\
\hline Socio-economic knowledge & 8.12 & 1.344 \\
\hline Knowledge of economic-financial management & 6.96 & 1.824 \\
\hline Socio-political knowledge & 8.54 & 1.207 \\
\hline Knowledge of corporate communications & 8.19 & 1.300 \\
\hline Marketing knowledge & 6.04 & 2.044 \\
\hline Knowledge of international relations & 7.34 & 1.714 \\
\hline Knowledge of organizational strategy & 7.72 & 1.802 \\
\hline Languages & 8.41 & 1.516 \\
\hline Written communication & 8.97 & 1.046 \\
\hline Oral communication & 9.42 & 0.702 \\
\hline Diplomatic and relationship skills & 9.11 & 0.987 \\
\hline Negotiating capacity and strategic vision & 9.12 & 1.046 \\
\hline Skills for the management and direction of work areas and teams & 8.19 & 1.246 \\
\hline
\end{tabular}

Table 5. Descriptive statistics for the 15 competences $(\mathrm{N}=72)$

In the cluster analysis performed, the conglomeration method referred to as the Ward method was used, and in terms of measurement, the squared Euclidean distance was used. The first division in two clusters has allowed researchers to determine that this result differs from the first classification that was made a priori, i.e., from the convenience sampling that was performed, which distinguished two types of managers (those who came from large corporations and those who came from business associations), as it does not show similarities in their answers. If their responses are analyzed, we see that they are not equivalent to the number of managers that was used in the study. Initially, the questionnaire was answered by 50 directors from large corporations and 22 leaders of business associations. However, based on the ratings given by the directors to the questions relating to professional skills, the two initial clusters consisted of 33 managers in the first cluster and 39 managers in the second cluster. If, at the same time, we analyze the composition of these first two clusters, there are responses of both sub-samples.

This indicates that the greater or lesser importance the managers surveyed give to a particular competence of a candidate to hold a position in institutional relations is not related to the type of organization in which he or she works (company or industry association). The analysis went on to identify three clusters, and it was finally decided to accept the option with four clusters, as can be seen in the dendrogram in Appendix 1. The composition of each cluster of individuals in the sample (managers) is as follows: cluster 1: 33 managers; cluster 2: 18 managers; cluster 3: 14 managers; cluster 4: 7 managers. 


\section{Conclusions}

The investigation led to the elaboration of a job description for the person responsible for institutional relations in major Spanish companies and business associations, based on the answers given by experts, APRI directors and the subjects surveyed (72 institutional relations managers).

The profile of the person responsible for institutional relations of a corporation or business association is as follows:

\begin{tabular}{|l|l|}
\hline Name of the position & Institutional relations practitioner \\
\hline Department & Institutional Relations \\
\hline Area & Strategy/Control \\
\hline Reports to & General Administration/CEO \\
\hline General function of the job position \\
\hline Promotion and development of the institutional relations of the corporation or business association \\
\hline
\end{tabular}

Tasks to be performed in the job position

Defending the legitimate interests of the company, transmitting these interests to those responsible for decision-making and ensuring that the interest of the company is taken into consideration

\begin{tabular}{|c|c|}
\hline $\begin{array}{l}\text { PROFESSIONAL } \\
\text { COMPETENCES } \\
\text { REQUIRED (cognitive } \\
\text { component) }\end{array}$ & $\begin{array}{l}\text { Socio-political knowledge } \\
\text { Socio-economic knowledge } \\
\text { Knowledge of organizational strategy } \\
\text { Marketing knowledge } \\
\text { Knowledge of economic-financial management }\end{array}$ \\
\hline $\begin{array}{l}\text { PROFESSIONAL } \\
\text { COMPETENCES } \\
\text { REQUIRED (procedural } \\
\text { component) }\end{array}$ & $\begin{array}{l}\text { Oral communication } \\
\text { Knowledge about the decision-making process } \\
\text { Written communication } \\
\text { Knowledge of current legislation } \\
\text { Negotiating capacity and strategic vision }\end{array}$ \\
\hline $\begin{array}{l}\text { PROFESSIONAL } \\
\text { COMPETENCES } \\
\text { REQUIRED (relational } \\
\text { component) }\end{array}$ & $\begin{array}{l}\text { Skills for the management and direction of work areas and teams } \\
\text { Diplomatic and relationship skills } \\
\text { Knowledge of corporate communications }\end{array}$ \\
\hline $\begin{array}{l}\text { PROFESSIONAL } \\
\text { COMPETENCES } \\
\text { REQUIRED (international } \\
\text { component) }\end{array}$ & $\begin{array}{l}\text { Knowledge of international relations } \\
\text { Languages }\end{array}$ \\
\hline $\begin{array}{l}\text { INITIAL TRAINING } \\
\text { REQUIRED }\end{array}$ & Public Relations/Business Administration and Management \\
\hline EXPERIENCE REQUIRED & $\begin{array}{l}\text { Knowledge of the activity sector in which the position will be conducted, } \\
\text { international professional experience }\end{array}$ \\
\hline NOTES & $\begin{array}{l}\text { Description of the position of the person responsible for institutional } \\
\text { relations of a corporation or business association. It does not include } \\
\text { consultants, communications agencies, law firms or others }\end{array}$ \\
\hline
\end{tabular}

Figure 2. Job description of the institutional relations practitioner

The job description that has been made is applicable to the need for these professionals in both large organizations and business associations. Is transversal and generic.

Subsequently, a hierarchical cluster analysis was performed on the factors of the principal component analysis, which made it possible to identify the clustering of managers in terms of the prioritization of the desired competences for the job position. It was possible to distinguish 4 clusters:

Functional cluster: These are those managers who value the procedural component or factor above the other three, i.e., they believe that professionals in institutional relations must have knowledge about the decisionmaking process for matters that affect the interests of the organization, have a good capacity for both oral and 
written communication, have a strategic vision of the business and have knowledge of current legislation in the country. The second most important component is the relational component, in which diplomatic and relationship skills, along with team management skills, are considered extremely important. In spite of the fact that cognitive aspects are also highly valued, they believe that those related to economic-financial knowledge, marketing knowledge and international relation knowledge are not relevant. The factor with relative importance for these managers is the "international" component, since they give greater importance to languages and knowledge of international relations. Of the four clusters studied, it is the one that has produced the least significant differences, if we compare the principal components, although the evaluation is stricter. This is because they believe that knowledge of marketing and with regard to economic-financial matters should not be an essential requirement for the performance of this job profile.

Comprehensive cluster: These are those managers who value all the components in a very similar manner, and they therefore represent those possible employers who seek a professional profile for the person in charge of institutional relations that is equivalent to that found in the principal components study. In addition, their scores are higher than those of the other three clusters. In conclusion, it is the group that seeks a professional profile similar to that defined in the principal components analysis, where all the components are rated in the same proportion.

Relational cluster: This cluster consists of those managers who value very positively the relational and procedural competences in the profile being sought, as well as international competences. In reference to the cognitive component, they exclude two competences that they believe should not form part of the requirements for this profile: knowledge about marketing and organizational strategy. They are strict in their scoring, but in general, they agree on the identified profile.

Classic cluster: This cluster is made up by managers who are looking for a more cognitive and procedural profile than a relational and international one. They surely make up a more "classic" group, since they believe that theoretical training is relevant and assuredly are seeking a less pragmatic profile, and thus experience does not seem to be considered important for this professional.

In summary, the study has allowed us to define a description of profile based on competences for a person responsible for institutional relations in Spain. The differences that arise between the clusters are derived primarily from the relative importance that the managers give to the competences studied, as opposed to an assessment of their relevance or lack thereof.

\section{Limitations and future research}

It should be emphasized that the sample used for the study is a convenience sample at the discretion of the researchers, although it represents an important number of companies (31.3\%) having institutional relations departments (50 out of a total of 160 companies). In any case, the sample comes from the Association of Professionals of Institutional Relations of Spain (APRI), a non-profit organization to which such professionals belong. The professional members of the Association strive to carry out actions aimed at greater transparency in the system. This has already led to the signing of a code of conduct which must be followed by all members and the creation of a voluntary public register of lobbyists among the members. For the reasons explained above, there is an unknown group of professionals who exercise functions in this type of job position, but who are not affiliated with said institution and their views might differ from those expressed in this work. In addition, there are other professionals, such as those employed by law firms, consulting firms, communication agencies and other types of organizations, whose views were not considered in this study. For this reason, it is difficult to generalize the results of this research to that kind of institutions and freelance professionals who exercise public affairs functions without being affiliated with the aforementioned institution.

The same limitation reveals to us that the functions exercised by institutional relations practitioners are closely linked to the defense of their clients, which, in this case, is their own business or industry association. This prevents knowing whether there are other functions, as mentioned by Von den Driesch and Van der Wurff, such as the role of expert or mediator. 
Much remains to be done. This work represents only a first attempt to recognize a profession that, throughout the developed world, is exercised and that is not well constrained in terms of either its functions or the powers that its agents should have. This article is intended to provide assistance in the task of identifying and defining the specific aspects of professional performance, in order to achieve a more precise definition of what institutional relations or lobbying are, particularly in Spain.

\section{Declaration of Conflicting Interests}

The authors declared no potential conflicts of interest with respect to the research, authorship, and/or publication of this article.

\section{Funding}

The authors received no financial support for the research, authorship, and/or publication of this article.

\section{References}

Allen, G. (2012). Public affairs practice in Australia. Journal of Public Affairs, 12(1), 77-80 https://doi.org/10.1002/pa.409

Álvarez, Ma I., \& De Montalvo, F. (2014). Los lobbies en el marco de la Unión Europea: Una reflexión a propósito de su regulación en España. Teoría y Realidad Constitucional, UNED, 33, 353-376. https://doi.org/10.5944/trc.33.2014.13025

APRI (2016). Quiénes somos. Retrieved from: http://relacionesinstitucionales.es/apri-asociacion-de-profesionales-derelaciones-institucionales/quienes-somos/

Bartlett Castellà, E., \& Vèrnia Trillo, S. (2015). La Regulació del Registre de Grupsd'interès a la llei 19/2014, del 29 de desembre, de Transparència, accés a la informació pública i bon govern. Revista catalana de dret públic, 51, 191-208. DOI: 10.2436/20.8030.01.61.

Berg, K. (2009). Finding connections between lobbying, public relations and advocacy. Public Relations Journal, 3(3), 1-19.

Beurer-Züllig, B., Fieseler, C., \& Meckel, M. (2009). Typologies of communicators in Europe. Corporate Communications: An International Journal, 14(2), 158-175. https://doi.org/10.1108/13563280910953843

Chiavenato, I. (1999). Administración de Recursos Humanos (5th Ed.). Bogotá, D.C.: McGraw Hill.

De Lange, R. (2000). Public affairs practitioners in the Netherlands: A profile study. Public Relations Review, 26(1), 15-29. https:// doi.org/10.1016/S0363-8111(99)00029-6

De Lange, R., \& Linders, P. (2006). Public affairs as reality construction: An established paradigm with new implications. Journal of Public Affairs, 6(2), 131-146. https://doi.org/10.1002/pa.222

Davidson, S. (2015). Everywhere and nowhere: theorising and researching public affairs and lobbying within public relations scholarship. Public Relations review, 41(5), 615-627. https://doi.org/10.1016/j.pubrev.2014.02.023

Dennis, L.B. (1996). Practical Public Affairs in an Era of Change: A Communications Guide for Business, Government, and College. Lanham, MD: University Press of America.

Fleisher, C.S. (2001). Emerging US public affairs practice: the 2000+ PA model. Journal of Public Affairs, 1(1), 44-52. https://doi.org/10.1002/pa.49

Harris, P., \& Fleisher, C.S. (2005). Handbook of Public Affairs (1st Ed.). London: Sage Publications.

Harris, P., \& Moss, D. (2001). In search of public affairs: A function in search of an identity. Journal of Public Affairs, 1(2), 102-110. https://doi.org/10.1002/pa.55

Hawkinson, B. (2005). The internal environment of public affairs: Organization, process, and systems. In P. Harris, \& C.S. Fleisher (Eds.), Handbook of Public Affairs (pp. 76-85). London: Sage Publications. https://doi.org/10.4135/9781848608108.n6 
Jerez, M., (2000). Los grupos de presión (2 ${ }^{\text {nd }}$ Ed.). Madrid: Del Águila, R Ediciones.

L'Etang, J (2008). Public Relations: Concepts, Practice and Critique. London: Sage Publications.

Lerbinger, O. (2006). Corporate Public Affairs: Interacting with Interest Groups, Media, and Government. Mahwah, NJ: Lawrence Erlbaum Associates. https://doi.org/10.4324/9781410617262

Levy-Leboyer, C. (2003). Gestión de las Competencias. Barcelona: EdicionesGestión 2000.

López-Roldán, P., \& Fachelli, S. (2016). Análisis de clasificación. In P. López-Roldán \& S. Fachelli, Metodología de la Investigación Social Cuantitativa. Bellaterra (Cerdanyola del Vallès): Dipòsit Digital de Documents, UniversitatAutònoma de Barcelona. Capítulo III.12. $1^{\text {a }}$ edición. Versión 2. Digital Edition: http://ddd.uab.cat/record/142929

López-Roldán, P., \& Fachelli, S. (2016). Análisis factorial. In P. López-Roldán \& S. Fachelli, Metodología de la Investigación Social Cuantitativa. Bellaterra (Cerdanyola del Vallès): Dipòsit Digital de Documents, UniversitatAutònoma de Barcelona. 1a edición, versión 3. Digital Edition: http://ddd.uab.cat/record/142928

Lord, M. (2000). Corporate political strategy and legislative decision making: the impact of corporate legislative influence activities. Business \& Society, 39(1), 76-93. https://doi.org/10.1177/000765030003900106

Louart, P. (1994). Gestión de los Recursos Humanos. Barcelona: Ediciones Gestión 2000.

Marcus, AA, \& Irion, M.S. (1987). The continued growth of the corporate public affairs function. The Academy of Management Executive, 1(3), 247-250. https://doi.org/10.5465/ame.1987.4275760

McGrath, C., Moss, D., \& Harris, P. (2010). The evolving discipline of public affairs. Journal of Public Affairs, 10(4), 335-352. https://doi.org/10.1002/pa.369

Milbrath, L. (1963). The Washington Lobbyists. Chicago: Rand McNally.

Mondy, R.W., \& Noe, R.M. (1997). Administración de Recursos Humanos. Prentice Hall.

Morata, F. (1995). Influir para decidir: la incidencia de los lobbies en la Unión Europea. Revista de estudios políticos, $90,131$.

PAC (2016). Public Affairs Council European Office. Retrieved from: http://pac.org/europe

Post, J. (1982). Public affairs: Its role. The Public Affairs Handbook (pp 23-30). Nagelschmidt JS (ed). Amacom: New York.

Rubio Núñez, R. (2003). Los grupos de presión. Centro de EstudiosConstitucionales.

Toth, E.L. (1986). Broadening research in public affairs. Public Relations Review, 12(2), 27-36. https://doi.org/10.1016/S0363-8111(86)80024-8

Transparency International España (2014). Una Evaluación del Lobby en España. Retrieved from: http://transparencia.org/

Tusinki, B. (2009). Finding connections between lobbying, public relations and advocacy. Public Relation Journal, 3, $1-19$.

Von den Driesch, D., \& Van der Wurff, R. (2016). Role conceptions of public affairs practitioners in The Netherlands. Public Relations Review, 42(3), 441-450. https://doi.org/10.1016/j.pubrev.2015.11.011

Windsor, D. (2005). Theories and theoretical roots of public affairs. The handbook of public affairs (pp. 401-417). Harris P., Fleisher, C.S. (Eds.). https://doi.org/10.4135/9781848608108.n24

Xifra, J. (2011). El lobbying europeo: Scenario y bases para sudesarrollo, Organicom, 8(14 primer semester), 169. 


\section{Appendix 1}

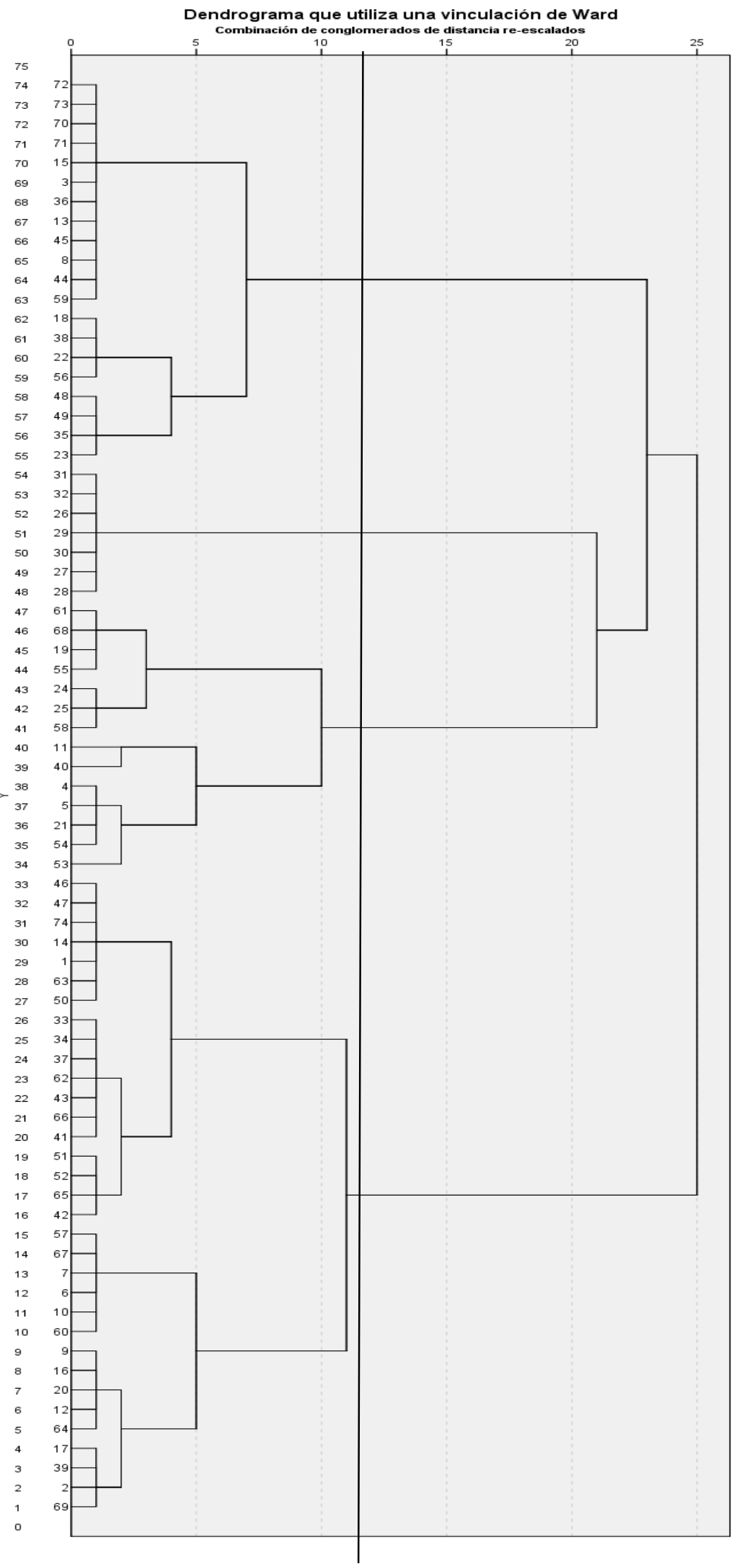

Figure 1. Dendrogram with Ward linkage 
Intangible Capital, 2018 (www.intangiblecapital.org)

\section{(c) (1) \$}

Article's contents are provided on an Attribution-Non Commercial 4.0 Creative commons International License. Readers are allowed to copy, distribute and communicate article's contents, provided the author's and Intangible Capital's names are included. It must not be used for commercial purposes. To see the complete license contents, please visit https://creativecommons.org/licenses/by-nc/4.0/. 